
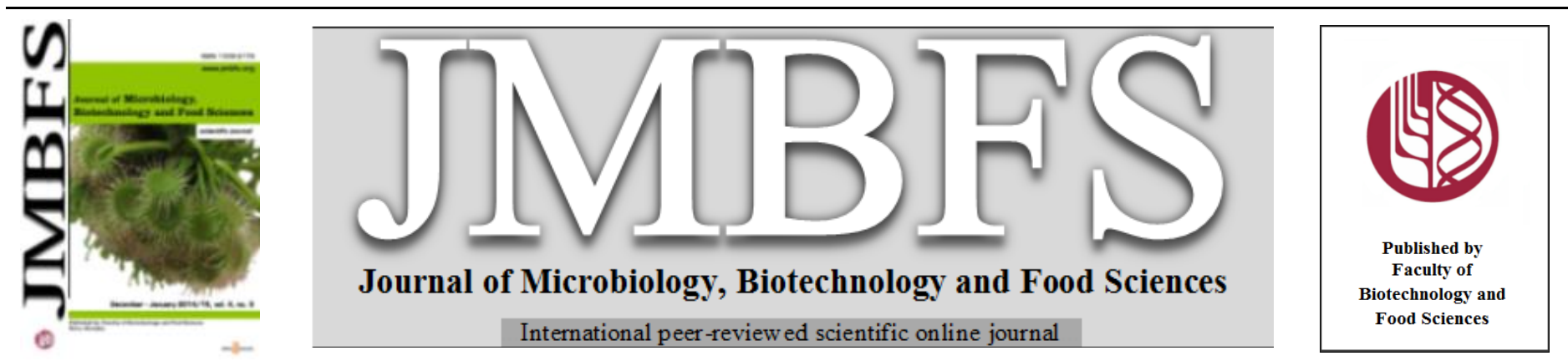

\title{
INHIBITION OF COXACKIE VIRUS B3 IN MICE USING METHANOLIC EXTRACT OF CALLIANDRA HAEMATOCEPHALA
}

\author{
Mohamed Shaheen ${ }^{\prime}{ }^{1}$, Mamdouh El-Gamal $^{2}$, Adel Mousa $^{2}$, Samy Mostafa ${ }^{3}$, Nagwa El-Esnawy ${ }^{1}$ \\ Address(es): Dr. Mohamed Shaheen, \\ ${ }^{1}$ National Research Center, Department of Water Pollution Research, Environmental Virology Laboratory, El-Buhouth Street, Post code: 12622, Dokki, Cairo, Egypt, \\ +201221107605 . \\ ${ }^{2}$ Al-Azhar University, Faculty of Science, Department of Botany and Microbiology, Post code: 11884, Cairo, Egypt, +201006629655. \\ ${ }^{3}$ National Research Center, Department of Medicinal and Aromatic Plants Research, El-Buhouth Street, Post code: 12622, Dokki, Cairo, Egypt, +201008643620.
}

*Corresponding author: $\underline{m}$ nrc2007@yahoo.com

doi: 10.15414/jmbfs.2014-15.4.3.257-262

ARTICLE INFO

Received 3. 4. 2014

Revised 15. 9. 2014

Accepted 29. 10. 2014

Published 1. 12. 2014

Regular article

open $\mathcal{O}_{\text {ACCESS }}$

\begin{abstract}
Coxsackie virus B3 (CVB3) represents current major threats to public health and considers as an important viral pathogen related to viral myocarditis. We determined the safety of methanolic extract of Calliandra haematocephala in non-infected mice then two safe doses were selected to be evaluated in infected mice with CVB3 by determining the morbidity, mortality, heart to body weight ratio (HW/BW), virus titers in heart tissue. The effect of the extract on the heart tissues and the activities LDH, AST, and CK enzymes in the mice infected with CVB3 were also determined. Our results recorded that the methanolic extract at $100 \mathrm{mg} / \mathrm{kg}$ body was safe dose in mice and didn't shown significant changes in funtions or histological structures of liver and kindey in non-infected mice and therefore we used $100 \mathrm{mg} / \mathrm{kg}$ and $50 \mathrm{mg} / \mathrm{kg}$ to be evaluated in infected mice with CVB3. We observed that the methaolic extract of Calliandra haematocephala leaves at the two doses decreased the morbidity, mortality, HW/BW, virus titers, necrosis and mononuclear cell infiltration. The levels of LDH, AST, and CK enzymes were also reduced in the treated infected mice compared with those untreated infected mice. This result suggested that the methaolic extract of Calliandra haematocephala may represent a potential antiviral drug to treatment viral myocarditis
\end{abstract}

Keywords: Callindra, antiviral, in vitro, in vivo, CVB3

\section{INTRODUCTION}

Enteroviruses, including coxackie-, polio-, echo-, and enteroviruses 68-71, are characterized by small RNA viruses in the picornaviridae family (Rajtar et al., 2008). Coxackieviruses can be divided into group $A$ and $B$ based on the difference in the pathogenicity in mice. The group A coxackieviruses include 23 serotypes whereas the group B coxackieviruses include 6 serotypes (Mahy, 2008; Melnick, 1996). Coxackieviruses can cause wide variety of illness in human including myocarditis, diabetes, common cold, neurological disorders, cardiomyopathy, and inflammation (Galbraith et al., 1997; Fohlman et al., 1993; Muir et al., 1996; Ramsingh et al., 1997). Heart diseases caused by viral myocarditis have been reported in infant, children, and adult. Although there is many viruses such as adenovirus, Epstein-Barr virus, parvovirus, Herpes virus type 6, cytomegalovirus, hepatitis C virus cause myocarditis (Bowles et al., 2003; Kindermann et al., 2008; Kuhl et al., 2005a,b;Kyto et al., 2005; Mahrholdt et al., 2006; Matsumori, 2005; Matsumori et al., 2006), however coxackieviruses and specially type B3 consider the main ethiological pathogen for myocarditis (Blauwet, 2010; Kuhl et al., 2005'a ; Mahrholdt et al., 2006). Coxacki B3 virus is responsible for more than fifty percent of all viral myocarditis cases (Shen et al., 2009). However up to now, there are no specific drugs or vaccines available to clinical treatment of CVB3 infection. Development of antiviral agents from medicinal plants are increasing day by day in the worldwide because it consider as cheap and safe sources for both animal and human. So, the aim of the present work was to evaluate the antiviral activity of methanolic extract obtained from Calliandra haematocephala leaves against coxackie $\mathrm{B} 3$ virus in vivo.

Calliandra haematocephalabelongs to the family Fabaceae (Bailay, 1976; Benson, 1957; Williamson, 1981) is native to tropical America and widely distributed in various regions such as Australia, South Florida, Malaysia, and Egypt (Williamson, 1981). Phytochemical screening of the methanolic extract of C. haematocephala leaves is reported to contain carbohydrate, protein, alkaloids, flavonoid, steroid, and glycoside (Gupta et al., 2013). C. haematocephala is reported also to contain betulinic acid (Nia et al., 1999). The betulinic acid act as an anti-inflamatory, anti-tumor and anti-HIV agents (Potier, 1991; Kashiwada et al., 1996).C. haematocephala showed various pharmacological properties such as antibacterial (Nia et al., 1999), Anti-oxidant (Moharran et al., 2006), and gastroprotective activities(Barbosa et al., 2012).

\section{MATERIAL AND METHODS}

\section{Plant collection and identification}

C. haematocephalaleaves were collected from the National Research Centre Botanical Garden during the period May and June 2012, and was kindly identified by, Mrs. Tersea Labib, taxonomist at Orman Botanical garden, Giza and Dr. Mona Marzok, researcher in National Research Center (NRC).

\section{Extraction with different organic solvents}

The fresh leaves of C.haematocephalawere dried at room temperature in shad and grinded to fine powder. Air dried fine powdered of $C$. haematocephalaleaves was extracted by methanol in percolator at room temperature till exhausted, and evaporated till dryness in rotary evaporator at $40{ }^{\circ} \mathrm{Cthen} \mathrm{kept} \mathrm{in} \mathrm{refrigerator} \mathrm{until}$ use.

\section{Cell culture and virus}

Green monkey kidney (GMK) and coxsackievirus B3 (Nancy) strain wereobtained from the Slovak Medical University. GMK cells were cultivated in Eagle's minimum essential medium (EMEM) (Lonza, Belgium) supplemented with $10 \%$ heat inactivated fetal bovine serum (FBS), 100 units $/ \mathrm{ml}$ penicillin, $100 \mu \mathrm{g} / \mathrm{ml}$ streptomycin, and 1\%HEPES (4-2-hydroxyethyl-1piperazineethanesulfonic acid). All reagents were puchased from Lonza, Belgium.The medium used for the cytotoxicity and antiviral assays contained $2 \%$ of the appropriate fetal bovine serum. Viral CVB3 stocks were prepared in GMK cells and kept at $-80^{\circ} \mathrm{C}$ until used. 


\section{Virus titration}

Virus was titrated on GMK cells in 96 well microtiter plates as described previously (Bopegamage et al., 2003). Tissue culture infectious doses $/ \mathrm{m}$ $\left(\mathrm{TCID}_{50} / \mathrm{ml}\right)$ were calculated using Kärber method (Karber, 1931).

\section{Cytotoxicity determinations in vivo}

BALB/c male mice, 4 weeks old (17-20 g) were obtained from animal house of National Research Center, Cairo, Egypt. Mice were divided into 6 groups of 10 mice. Five groups were treated by different concentrations of methanolic extract of $C$. haematocephala $(100,250,500,750$ and $1000 \mathrm{mg} / \mathrm{kg}$ body weight/day), one control group. Mortality of mice was controled daily during the 8 weeks.

Effect ofmethanolic extract of $C$. haematocephala leaves on liver and kidney function and structure sub-chronictoxicity

Biochemical measurements and the serum glucose level were analysed by an enzymatic colorimetric method. The liver function tests such as the activities of serum albumin, total billirubin, aspartate transaminase (AST), alanin transaminase (ALT), alkaline phosphatase (ALP), and gamma glutamyltransferase $(\gamma$ - GT) levels as well as serum glucose and kidney function tests such as creatinine and urea nitrogen, and total protein levels were also measured spectrophotometrically by standardized commercial kits as described by (Webster, 1974; Friedman and Young, 1997; Bergmyer et al.1986a; Bergmyer et al. 1986b; Belfield and Goldberg, 1971; Szasz, 1969; Trinder, 1959; Tabacco et al., 1979; Bartels and Bohmer, 1971; Cannon et al. 1974). All kits were purchased from BIODIAGNOSTIC (29 El-Tahrer St. - Dokki- Giza - Egypt).

\section{Antiviral activity}

Forty BALB/c male mice, 4 weeks old (17-20 g) obtained from animal house of National Research Center in Cairo were used in this study. These mice were divided into 5 groups of 8 each. Of which, four groups of mice were infected intraperritoneally with CVB3 $\left(10^{4} \mathrm{TCID}_{50} / 0.1 \mathrm{ml}\right)$ and the remaining group was used as negative control and was similarly injected intrapritoneally with $0.1 \mathrm{ml}$ of PBS (phosphate saline buffer) without viruses. After additional 24 hours, twenty four of inoculated mice were orally given methanolic extract $(100 \mathrm{mg} / \mathrm{kg}$ body weight/day, $\mathrm{n}=8 \& 50 \mathrm{mg} / \mathrm{kg}$ body weight/day, $\mathrm{n}=8$ ) or injected intraperritoneally with ribavirin, which were used as positive control at a dose of $10 \mathrm{mg} / \mathrm{kg}(\mathrm{n}=8)$ daily for 7 days. Eight inoculated mice were treated with $0.9 \% \mathrm{NaCl}$ solution daily and used as infected control. The negative control $(n=8)$ were given orally $0.9 \% \mathrm{NaCl}$ solution daily. The morbidity (such as trembling, loss of appetite, diminished vitality, ruffled fur, and weight loss) and mortality were recorded daily during the 7 -d experiment.

Mice were sacrificed on day 7 (4 in each group) after viral exposure. Blood was collected from the eye sockets and separated into serum to determine the lactic dehydrogenase(LDH) (Biosystem, Spain), creatine kinase(CK) (Spinreact, Spain), and aspartate transaminase(AST) (Randox, UK) activities by using commercially available kits. The ratio of $\mathrm{BW} / \mathrm{HW}$ as the heart index was determined by measuring the body weight (BW) and heart weight (HW) of each mice. The heart was divided into two parts, one part of the hearts of mice in each group was homogenized in $1.5 \mathrm{ml}$ of test medium followed by frozen and thawed twice to release CVB3 from heart tissue then centrifuged at $1200 \mathrm{xg}$ for $15 \mathrm{~min}$. Virus titers was determined by the plaque assay with GMK cells (Bishop and Koch, 1969). The other part of the hearts of mice in each group were fixed in $10 \%$ buffered then sectioned ( $4 \mu \mathrm{m}$ thick) and stained with hematoxylin-eosin Sections of hearts were scored for myocardial necrosis as described previously (Zhang et al., 2006). Photographs for myocarditis signs were taken under an inverted microscope using camera (Cannon). The remaining four mice of each group were checked daily to determine the changes in body weight and any deaths.

\section{Statistical analysis}

All data obtained were expressed as mean, \pm S.D., and examined by one way analysis of variance (ANOVA), CoStat Computer Program. A probability values of less than 0.05 was regarded as statistically significant.

\section{RESULTS AND DISCUSSION}

\section{Cytotoxicity determinations in vivo}

For the acute toxicity study, $100,250,500,750$ and $1000 \mathrm{mg} / \mathrm{kg}$ body weight of the $C$. haematocephala methanolic extract were administered through orally to mice and obvious symptoms of toxicity and mortality were monitored for 8 weeks. Dose $100 \mathrm{mg} / \mathrm{kg}$ body weight of methanolic extract induces $10 \%$ mortality of mice. Administration of $C$. haematocephala methanolic extract at concentrations of $250,500,750$ and $1000 \mathrm{mg} / \mathrm{kg}$ body weight recorded mortality mice by $30 \%$ (Tab. 1). So, $100 \mathrm{mg}$ of methanolic extract $/ \mathrm{kg}$ body weight was selected as safe dose to determine the biochemical indices in mice. Unfortunately, no litratures were found concenring the cytotoxicity of methanolic leave extract of $C$. haematocephala. However, ethanolic leaf extract of another species of genus Calliandra(Calliandra portoricensis) was found to be safe with $\mathrm{LD}_{50}=150 \mathrm{mg} / \mathrm{kg}$ (Onyema et al., 2012).

Table 1 Mortality rates of mice after administration of extract at different concentrations

\begin{tabular}{|c|c|c|c|c|}
\hline Plants & $\begin{array}{l}\text { Concentrations/kg } \\
\text { body weight }\end{array}$ & $\begin{array}{l}\text { Number } \\
\text { of mice } \\
\text { in each }\end{array}$ & $\begin{array}{l}\text { Number } \\
\text { of dead } \\
\text { animals }\end{array}$ & $\begin{array}{l}\text { Mortality } \\
\text { rate }\end{array}$ \\
\hline Control & 0.00 & 10 & 0 & $0 \%$ \\
\hline \multirow{5}{*}{$\begin{array}{l}\text { Methanolic extract of } \\
\text { C. } \\
\text { haematocephalaleaves } \\
\text { at different } \\
\text { concentrations }\end{array}$} & $100 \mathrm{mg}$ & 10 & 1 & $10 \%$ \\
\hline & $250 \mathrm{mg}$ & 10 & 3 & $30 \%$ \\
\hline & $500 \mathrm{mg}$ & 10 & 3 & $30 \%$ \\
\hline & $750 \mathrm{mg}$ & 10 & 3 & $30 \%$ \\
\hline & $1000 \mathrm{mg}$ & 10 & 3 & $30 \%$ \\
\hline
\end{tabular}

The effect of methanolic extract of $C$. haematocephala leaves on liver and kidney function and structure Sub-chronictoxicity

This study represent the first report concering the safety of methanolic leaf extract of $C$. haematocephala. The effects of daily oral administering dose at $100 \mathrm{mg} / \mathrm{kg}$ body weight of the extract for 8 weeks on albumin, bilirubin and glucose levels are shown in Tab. 2. The results showed that the extract did not cause any significant changes on the level of the albumin, bilirubin and glucose as compared to control group. Aminotransferases (ALT and AST) are produced in the liver and are good markers of liver cells damage (Rej, 1989). Administration of healthy mice with $C$. haematocephala methanolic extract at $100 \mathrm{mg} / \mathrm{kg}$ body weight caused significant decrease in the levels of liver function enzymes AST by 7.13 unit/ml (18.91\%) and ALT by $7.21 \mathrm{unit} / \mathrm{ml}(13.70 \%)$, The reduction in the level of AST and ALT at the 1st week was temporary and the level increased to the normal level at the 2 nd week and persisted to the end of the experiment(Tab. 3). The level of ALP was decreased in $1^{\text {st }}$ week of treatment by 14.19 units $/ \mathrm{ml}$ and then slightly increased from the 2 nd week until the 8 th week as compared to control group. However the extract didn't caused significant changes in the level of GGT along the experiment (Tab. 3)

Table 2 Effect of methanolic extract of C.haematocephala on liver function indices and glucose level in normal mice at different durations

\begin{tabular}{|c|c|c|c|c|c|c|c|c|c|}
\hline Parameters & Control & $1^{\text {st }}$ week & $2^{\text {nd }}$ week & $3^{\text {ed }}$ week & $4^{\text {th }}$ week & $5^{\text {th }}$ week & $6^{\text {th }}$ week & $7^{\text {th }}$ week & $8^{\text {th }}$ week \\
\hline $\begin{array}{l}\text { Albumin } \\
\text { g/dL }\end{array}$ & $3.65 \pm 0.32^{\mathrm{a}}$ & $3.48 \pm 0.23^{\mathrm{a}}$ & $3.81 \pm 0.13^{\mathrm{a}}$ & $3.86 \pm 0.57^{\mathrm{a}}$ & $3.81 \pm 0.40^{\mathrm{a}}$ & $3.91 \pm 0.41^{\mathrm{a}}$ & $3.84 \pm 0.32^{\mathrm{a}}$ & $3.76 \pm 0.43^{\mathrm{a}}$ & $3.16 \pm 0.14^{\mathrm{a}}$ \\
\hline $\begin{array}{l}\text { Bilirubin } \\
\text { mg/dL }\end{array}$ & $0.50 \pm 0.08^{\mathrm{ab}}$ & $0.47 \pm 0.06^{\mathrm{ab}}$ & $0.53 \pm 0.04^{\mathrm{ab}}$ & $0.53 \pm 0.06^{\mathrm{ab}}$ & $0.42 \pm 0.06^{\mathrm{b}}$ & $0.53 \pm 0.07^{\mathrm{ab}}$ & $0.51 \pm 0.05^{\mathrm{ab}}$ & $0.62 \pm 0.09^{\mathrm{a}}$ & $0.55 \pm 0.05^{\mathrm{ab}}$ \\
\hline $\begin{array}{l}\text { Glucose } \\
\text { mg/dL }\end{array}$ & $82.40 \pm 2.61^{\mathrm{ab}}$ & $77.73 \pm 5.67^{b}$ & $76.93 \pm 2.70^{b}$ & $82.88 \pm 2.93^{\mathrm{ab}}$ & $81.74 \pm 2.76^{\mathrm{ab}}$ & $77.47 \pm 2.77^{\mathrm{b}}$ & $77.17 \pm 4.70^{b}$ & $79.23 \pm 3.62^{\mathrm{ab}}$ & $86.53 \pm 3.52^{\mathrm{a}}$ \\
\hline
\end{tabular}

- $\quad$ Data are means \pm SD of five mice in each group.

- ${ }^{a, b}$ significance values at $\mathrm{p} \leq 0.02$ for bilirubin and $\leq 0.007$ for glucose. 
Table 3 Effect of methanolic extract of $C$. haematocephala on liver function enzymes in normal mice at different durations

\begin{tabular}{|c|c|c|c|c|c|c|c|c|c|}
\hline Parameters & Control & $1^{\text {st }}$ week & $2^{\text {nd }}$ week & $3^{\text {ed }}$ week & $4^{\text {th }}$ week & $5^{\text {th }}$ week & $6^{\text {th }}$ week & $7^{\text {th }}$ week & $8^{\text {th }}$ week \\
\hline $\begin{array}{l}\text { AST } \\
\text { Unit/ml }\end{array}$ & $37.70 \pm 2.89^{\mathrm{a}}$ & $30.57 \pm 1.56^{\mathrm{b}}$ & $35.98 \pm 2.86^{\mathrm{a}}$ & $36.06 \pm 1.65^{\mathrm{a}}$ & $36.06 \pm 1.41^{\mathrm{a}}$ & $34.17 \pm 1.69^{\mathrm{ab}}$ & $33.74 \pm 1.28^{\mathrm{ab}}$ & $33.96 \pm 1.6^{\mathrm{ab}}$ & $36.73 \pm 2.59^{\mathrm{a}}$ \\
\hline $\begin{array}{l}\text { ALT } \\
\text { Unit/ml }\end{array}$ & $52.61 \pm 2.66^{\mathrm{a}}$ & $45.40 \pm 2.17^{\mathrm{b}}$ & $50.01 \pm 1.42^{\mathrm{a}}$ & $48.62 \pm 2.20^{\mathrm{a}}$ & $50.15 \pm 1.78^{\mathrm{a}}$ & $51.29 \pm 2.42^{\mathrm{a}}$ & $51.18 \pm 1.86^{\mathrm{a}}$ & $51.01 \pm 1.77^{\mathrm{a}}$ & $53.73 \pm 3.15^{\mathrm{a}}$ \\
\hline $\begin{array}{l}\text { ALP } \\
\text { Unit/L }\end{array}$ & $145.75 \pm 2.6^{\mathrm{a}}$ & $131.56 \pm 9.93^{\mathrm{a}}$ & $133.35 \pm 9.1^{\mathrm{a}}$ & $139.14 \pm 5.6^{\mathrm{a}}$ & $138.09 \pm 6.34^{\mathrm{a}}$ & $136.47 \pm 8.2^{\mathrm{a}}$ & $135.25 \pm 9.1^{\mathrm{a}}$ & $137.19 \pm 4.7^{\mathrm{a}}$ & $137.38 \pm 5.10^{\mathrm{a}}$ \\
\hline $\begin{array}{l}\gamma \text {-GT } \\
\text { Unit/L }\end{array}$ & $15.21 \pm 2.55^{\mathrm{a}}$ & $15.14 \pm 2.57^{\mathrm{a}}$ & $14.60 \pm 3.04^{\mathrm{a}}$ & $15.87 \pm 2.91^{\mathrm{a}}$ & $15.29 \pm 2.50^{\mathrm{a}}$ & $15.23 \pm 2.21^{\mathrm{a}}$ & $15.91 \pm 1.87^{\mathrm{a}}$ & $15.92 \pm 2.39^{\mathrm{a}}$ & $15.53 \pm 2.35^{\mathrm{a}}$ \\
\hline
\end{tabular}

- Data are means \pm SD of five mice in each group.

- $\quad{ }^{\mathrm{a}, \mathrm{b}}$ the significance values at $\mathrm{p} \leq 0.002$ for AST and $\leq 0.001$ for ALT

Kidney function indicators, changes in creatinine, urea and total protein were observed after administration of mice with the extract at dose $100 \mathrm{mg} / \mathrm{kg}$ body weight daily for 8 weeks. Tab. 4 shows that the changes were insignificant. They are normally present at low levels in the blood so if the liver cells are damaged, it would be expected that some of the enzymes leak into the blood and increase in levels. If there is tissue damage, some of these biomolecules find their way into the serum probably by leakage through altered membrane permeability (Akanji and Yakubu, 2000).

Table 4 Effect of methanolic extract of $C$. haematocephala on kidney function parameters in control mice at different durations

\begin{tabular}{|c|c|c|c|c|c|c|c|c|c|}
\hline Parameters & Control & $1^{\text {st }}$ week & $2^{\text {nd }}$ week & $3^{\text {ed }}$ week & $4^{\text {th }}$ week & $5^{\text {th }}$ week & $6^{\text {th }}$ week & $7^{\text {th }}$ week & $8^{\text {th }}$ week \\
\hline $\begin{array}{l}\text { Urea } \\
\text { mmol/L }\end{array}$ & $5.17 \pm 0.33^{\mathrm{ab}}$ & $3.89 \pm 0.45^{\mathrm{b}}$ & $4.13 \pm 0.78^{\mathrm{ab}}$ & $3.92 \pm 0.38^{\mathrm{b}}$ & $5.53 \pm 0.91^{\mathrm{a}}$ & $5.55 \pm 1.08^{\mathrm{a}}$ & $4.56 \pm 0.77^{\mathrm{ab}}$ & $4.64 \pm 0.34^{\mathrm{ab}}$ & $4.53 \pm 0.19^{\mathrm{ab}}$ \\
\hline $\begin{array}{l}\text { Creatinine } \\
\mu \mathrm{mol} / \mathrm{L}\end{array}$ & $35.25 \pm 2.50^{\mathrm{a}}$ & $32.85 \pm 1.88^{\mathrm{a}}$ & $34.75 \pm 2.66^{\mathrm{a}}$ & $35.00 \pm 2.58^{\mathrm{a}}$ & $35.25 \pm 3.86^{\mathrm{a}}$ & $34.00 \pm 2.58^{\mathrm{a}}$ & $32.75 \pm 2.50^{\mathrm{a}}$ & $34.54 \pm 2.64^{\mathrm{a}}$ & $35.75 \pm 1.71^{\mathrm{a}}$ \\
\hline $\begin{array}{l}\text { Total } \\
\text { protein } \\
\text { g/dL }\end{array}$ & $6.79 \pm 0.27^{\mathrm{a}}$ & $6.83 \pm 0.23^{\mathrm{a}}$ & $7.32 \pm 0.80^{\mathrm{a}}$ & $6.75 \pm 0.68^{\mathrm{a}}$ & $7.38 \pm 0.29^{\mathrm{a}}$ & $7.44 \pm 0.32^{\mathrm{a}}$ & $6.89 \pm 0.41^{\mathrm{a}}$ & $7.04 \pm 0.38^{\mathrm{a}}$ & $6.71 \pm 0.32^{\mathrm{a}}$ \\
\hline
\end{tabular}

- Data are means $\pm \mathrm{SD}$ of five rats in each group.

- $\quad$ a,b the significance values at $\mathrm{p} \leq 0.004$.

Microscopic examination of liver of control mice showed normal structure of the central vein, hepatocytes, and blood sinusoids (figure 1, A). Histopathological examination of sections of liver of the treated mice with the methanolic extract of C. haematocephala for 1-8 weeks showed the normal histological structure (figures 1, B-I) and normal architecture suggesting no morphological disturbances.

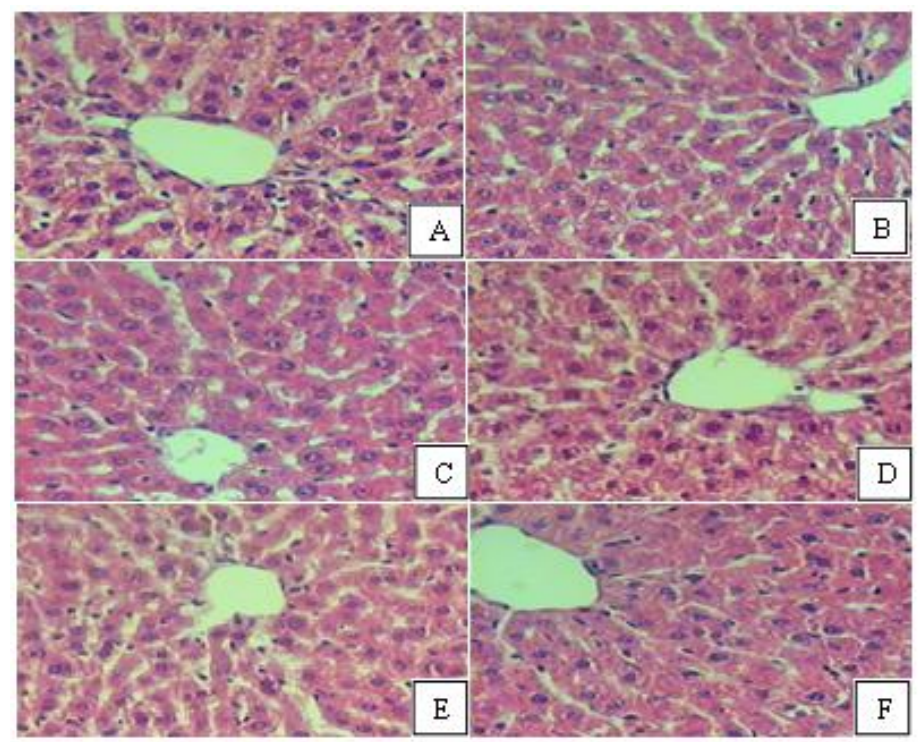

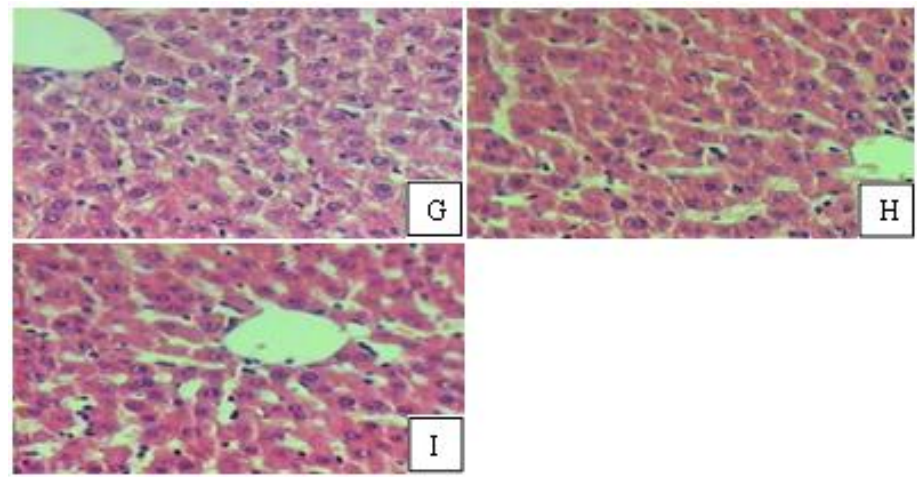

Figure 1 Sections of liver of mice treated with $C$. haematocephalamethanolic extract A) normal control, B) mice treated for 1 week, C) mice treated for 2 weeks, D) mice treated for 3 weeks, E) mice treated for 4 weeks, F) mice treated for 5 weeks, G) mice treated for 6 weeks, H) mice treated for 7 weeks and I) mice treated for 8 weeks showed normal structure (H \& E x 150).

Sections of cortical tissue of the kidney of control mice showed normal mice corpuscles, proximal convoluted tubules, and distal convoluted tubules (figure 2 , A).Histopathological investigation of sections of kidney of the treated mice with the methanolic extract of $C$. haematocephala for 1-8 weeks showed the normal histological structure (figure 2, B-I). 


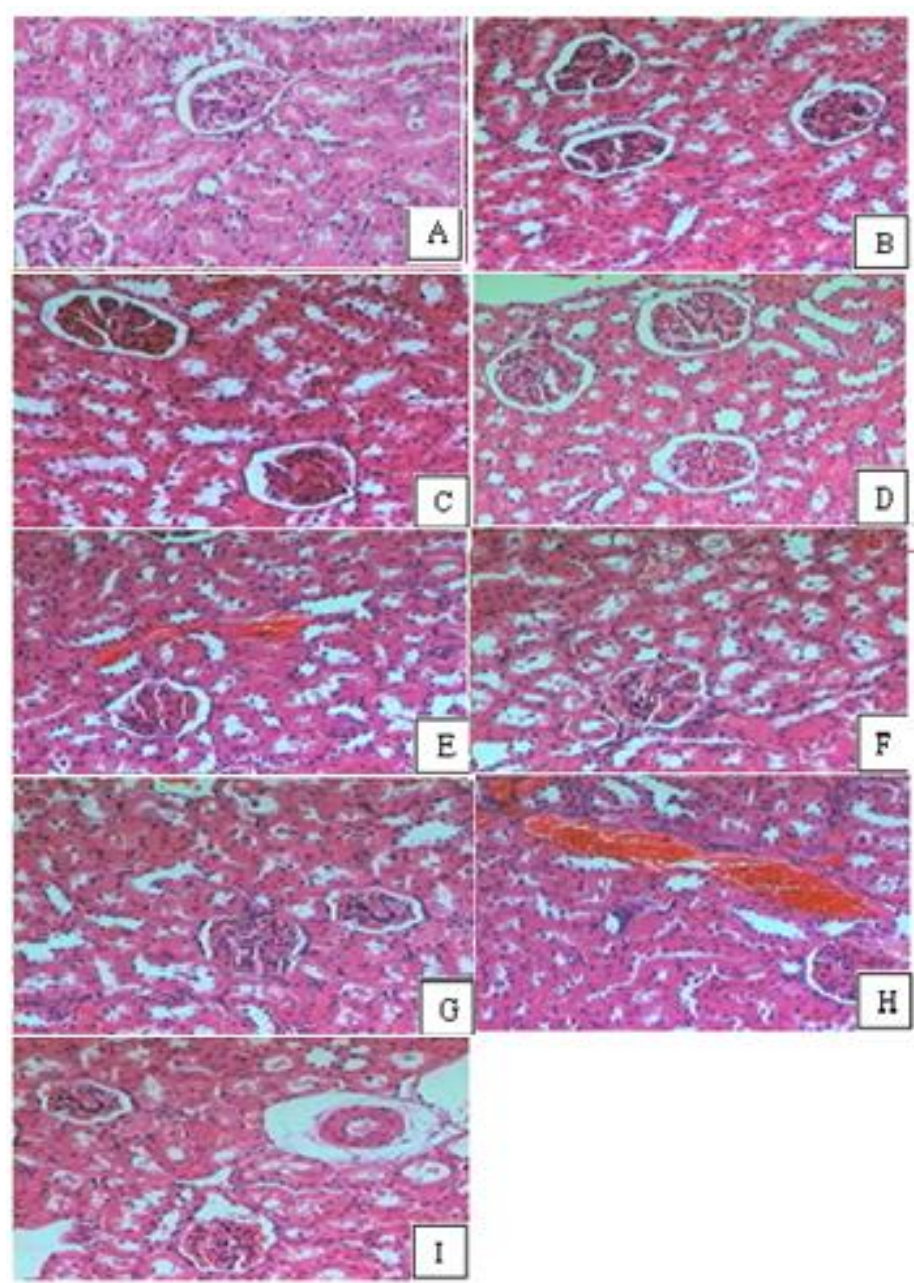

Figure 2 Sections of kidney of mice treated with $C$. haematocephala methanolic extract A) normal control, B) mice treated for 1 week, C) mice s treated for 2 weeks, D) mice treated for 3 weeks, E) mice treated for 4 weeks, F) mice treated for 5 weeks, G) mice treated for 6 weeks, H) mice treated for 7 weeks and I) mice treated for 8 weeks showed normal structure (H \& E x 150).
Morbidity, mortality, and $\mathrm{HW} / \mathrm{BW}$ ratios in vivo.

By day 3 after viral exposure, some mice especially in the viral control group showed morbids. The morbidity was $87.5 \%(7 / 8)$ in infected mice group while it reduced to $12.5 \%(1 / 8)$ and $25 \%(2 / 8)$ in mice treated with total alcohol of $C$. haematocephala at the doses of $100 \mathrm{mg} / \mathrm{kg}$ and $50 \mathrm{mg} / \mathrm{kg}$ respectively. The mortality was found on day 9 , some of mice especially in the viral infected control group began to die, and by 14 day, all of them had died. But there was no any deaths in the mice treated with the methanolic extract of $C$. haematocephala at the two doses $100 \mathrm{mg} / \mathrm{kg}$ and $50 \mathrm{~kg} / \mathrm{kg}$ (Tab. 6).

The HW/BW ratios were significantly increased in the infected control mice without treatment than that of those treated mice with the methanolic extract of C. haematocephala at the two dosages $(100 \mathrm{mg} / \mathrm{kg}$ and $50 \mathrm{~kg} / \mathrm{kg})$ compared with those in the normal control group (Tab.6).

\section{Virus titers of hearts in vivo experiment}

The virus titers were significantly decreased in the hearts of mice group treated with the methanolic extract of C.haematocephala leaves than that of those in the viral infected control group where the virus titers $4.32 \pm 0.23$ in the myocardia cells of the infected mice but significantly reduced to $2.41 \pm 0.85$ and $2.87 \pm 0.44$ in the myocardial cells treated with 100 and $50 \mathrm{mg}$ methanolic extract of $C$. haematocephala leaves (Tab. 6), indicating that the methanolic extract of C.haematocephala possess potent antiviral activity against coxackie B3 virus. The exact mechanism of viral inhibition by our extracts in treated mice is not clear. However, we suggest that the methanolic leaf extract may be inhibited the virus replication by blocking the coxsackievirus and adenovirus receptor (CAR) on host cells. CAR receptor is the primary receptor of CVB3 (Bergelson et al., 1997; Tomko et al., 1997) or by binding the extract to viral protein 1 (VP1) on the outer membran of the virus and prevented its attachment to receptor on host cells. the WIN compounds, WIN 54954, are antiviral agents by interacting with the hydrophobic pocket on the surface of the Coxackie B3 virus virion and inhibit interaction of the virion with the viral receptor (CAR) and thus prevent the virus attachment to the target cell receptors (Pevear et al., 1989). Finally, we suggest that the extract may be inhibited the viral replication by inhibition of RNA transcription or translation one or more of unstructured proteins $(2 \mathrm{~A}, 2 \mathrm{~B}, 2 \mathrm{C}, 3 \mathrm{~A}$, $3 \mathrm{~B}, 3 \mathrm{C}$, and 3D) of the viral genome in the infected cells. Nitric oxide (NO) have been reported to inhibit the coxackievirus replication via inactivation of proteases 2A and 3C by S-nitrosylation (Badorff et al., 2000; Saura et al.,1999). In another study, compounds, such guanidine hypochloride, HBB, MRL-1237 and TBZE-029 inhibited RNA synthesis by interacting with the viral protein 2C which led to protection of infected cell from lysis (De Palma et al., 2007 and 2008).

Table 6 Effect of methanolic extract of $C$. haematocephala leaves on mortality, the heart index, virus titers, and pathologic scores in BALB mice infected with CVB3 7 days after inoculation

\begin{tabular}{|c|c|c|c|c|c|}
\hline Group & Morbidity (\%) & $\begin{array}{l}\text { Mortality } \\
(\%)\end{array}$ & $\begin{array}{l}\text { HW/BW ratios } \\
\text { (means } \pm \text { S.D.) }\end{array}$ & $\begin{array}{l}\text { Virus titration } \\
\text { (means } \pm \text { S.D.) }\end{array}$ & $\begin{array}{c}\text { Pathologic } \\
\text { scores } \\
\text { (means } \pm \text { S.D.) }\end{array}$ \\
\hline Negative control group & 0 & 0 & $4.21 \pm 0.02$ & $0.00 \pm 0.00$ & $0.00 \pm 0.00$ \\
\hline Infected control group & 87.5 & 100 & $6.12 \pm 0.03$ & $4.32 \pm 0.01$ & $3.21 \pm 0.10$ \\
\hline Ribavirin (1 mg/mL) & $25^{*}$ & $25^{*}$ & $5.81 \pm 0.02 *$ & $3.45 \pm 0.03 *$ & $2.62 \pm 0.35^{*}$ \\
\hline $\begin{array}{l}\text { Methanolic extractof } \\
\text { C. haematocephala } 100 \mathrm{mg} / \mathrm{kg}\end{array}$ & $12.5^{*}$ & 0 & $4.31 \pm 0.01 *$ & $2.41 \pm 0.03 *$ & $0.75 \pm 0.03 *$ \\
\hline $\begin{array}{l}\text { Methanolic extractof } \\
\text { C. haematocephala } 50 \mathrm{mg} / \mathrm{kg}\end{array}$ & $25^{*}$ & 0 & $4.75 \pm 0.04 *$ & $2.87 \pm 0.03 *$ & $0.97 \pm 0.02 *$ \\
\hline
\end{tabular}

Effect of methanolic extract of $C$. haematocephala leaves on the activities of LDH, AST, CK.

The changes in the activities of lactic dehydrogenase (LDH), aspartate transaminase (AST), and creatine kinase (CK) is an indicator to injury to heart (Baba et al., 1976). We observed that the activities of LDH, AST, and CK enzymes were significantly increased in the serum of viral infected group than those observed in mice treated with methanolic extract of $C$. haematocephala at the two dosage (at $100 \mathrm{mg} / \mathrm{kg}$ and $50 \mathrm{mg} / \mathrm{kg}$ ), when they were compared to that in the normal control (figure 3).These results indicated that the methanolic leaf extract protected the cardiac tissue from the harmful effect of CVB3 and decreased the leakage of these enzymes to blood stream and therefor their levels in the serum of treated mice were found at normal values when compared with infected controlmice.

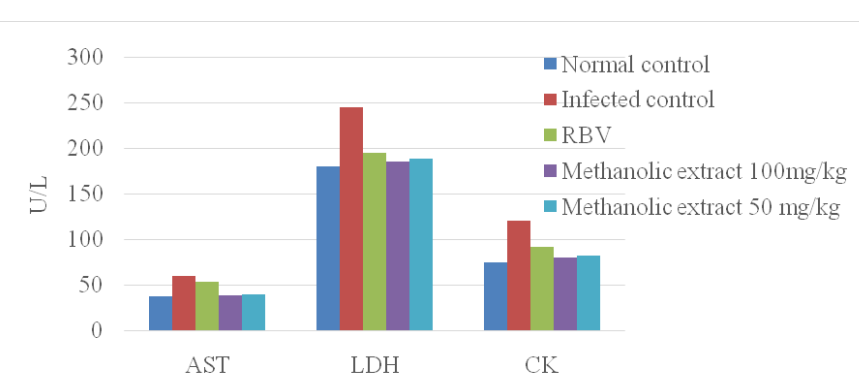

Figure 3 Effect ofmethanolic extract $C$. haematocephala leaves on the AST, $\mathrm{LDH}$, and $\mathrm{CK}$ activities in the serum of infected mouse on the $7^{\text {th }}$ day postinfection. * $p=0.01$, compared with the viral infected control. 


\section{Pathological findings}

The hearts of normal control group showed that the cardiac muscle cells have arrangement structure with clear nucleolus in addition to there were no necrotic cardiomyocyte and mononuclear cell infiltration in the normal myocardium. Tissue damage of cardiac muscle cells and scores of necrosis and infiltration were observed in viral infected control and ribavirin control while these signs were absent in the groups treated with methanolic extract from $C$. haematocephala leaves at the two doses $100 \mathrm{mg} / \mathrm{kg}$ and $50 \mathrm{mg} / \mathrm{kg}$ body weight/day(Figure 4).

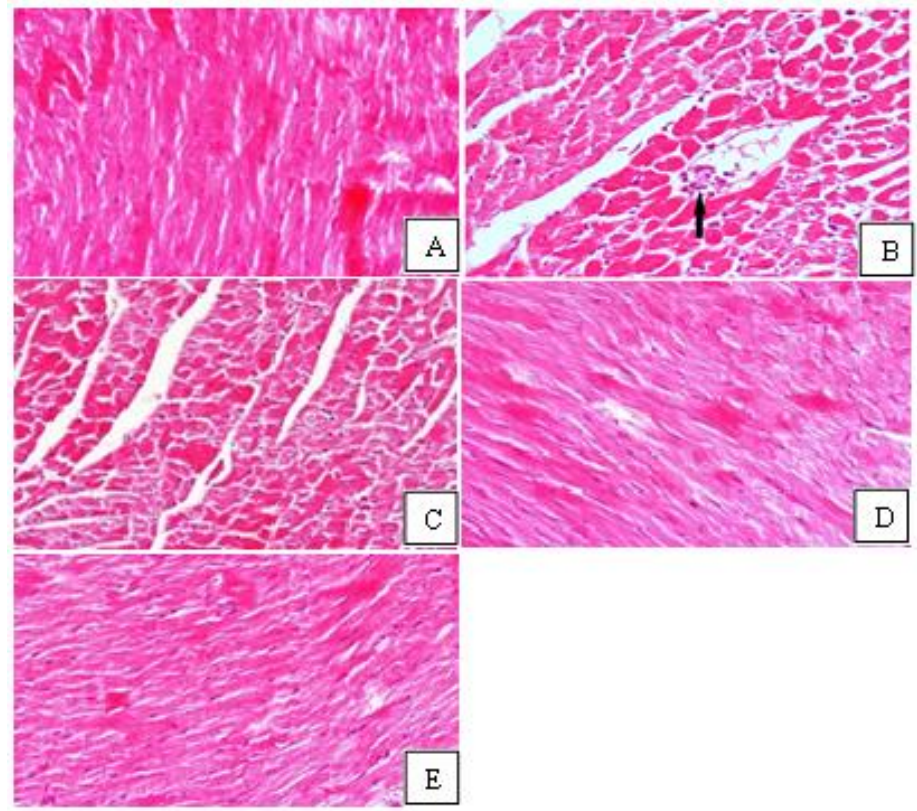

Figure 4 HE-stained sections of heart muscles from different groups. (A) norma control, (B) infected control showed mononuclear cell inflammation and myocardial necrosis, (C) RBV group, (D) C. haematocephala $100 \mathrm{mg} / \mathrm{kg}$ group, (E) C. haematocephala $50 \mathrm{mg} / \mathrm{kg}$ group.

As far as we know, this study represent the first report concerning evaluation of the antiviral activities of methanolic leaf extract of $C$. haematocephala. However, leaves of another species of genus Calliandra, Calliandra polytirsa, has been reported to have anti-hepatitis $C$ virus activities (Wahyuni et al., 2013). In addition, several plants or their constituents have been reported to possess antiviral activities against CVB3 in vivo. Among them, astragaloside IV from the roots of Radix Astragali plant was found to possess potent antiviral activities against CVB3 in mice (Zhang et al., 2006). Calycosin-7-O-b -D-glucopyranoside from the dried root of Astragalus membranaceus plant exerted significant antiviral activities against CVB3 both in vitro and in vivo (Zhu et al., 2009). Wang et al. (2009b) demonstrated that the Phyllaemblicin B, isolated from the root of Phyllanthus emblica plant, exerts significant antiviral activities against CVB3. 20(S)-Protopanaxtriol, isolated from the root of Panax notoginseng, has been reported to have antiviral effects on CVB3 virus-induced myocarditis in mice (Wang et al., 2012). Wang et al. (2009a) found that Salidroside, extracted from Rhodio rosea plant, possesses antiviral activities against CVB3 in mice and it may represent a potential therapeutic agent for viral myocarditis. Total flavonoid extracts, isolated from Selaginella moellendorffii plant, have been found to exhibit an effective antiviral activity against CVB3 infection in vitro and in vivo (Yin et al., 2014).

\section{CONCLUSION}

In the present study, we evaluated the safety as well as the antiviral activity of the methanolic extract of Calliandra haematocephalaleaves in mice. The antiviral activity was evaluated by determination of the morbidity, mortality, HB/BW ratios, virus titers, pathological scores, and AST, CK, and LDH activities. Our results showed that the extract is safe for medication use at $100 \mathrm{mg} / \mathrm{kg}$ body weight where niether mortality, nor signficant altrations in enzymes and morphological structures of liver and kidney organs. For antiviral activity, the infected mice treated with methanolic extract of $C$. haematocephala leaves at 100 $\mathrm{mg} / \mathrm{kg}$ and $50 \mathrm{mg} / \mathrm{kg}$ showed significant decreasingof mortality, $\mathrm{HB} / \mathrm{BW}$ ratios, virus titers, pathological scores, and AST, CK, and LDH activities than those in the viral infected control. These results indicate that the methanolic extract of $C$. haematocephala may represents as a potential antiviral agent for treatment of myocarditis causing coxackievirus.

\section{REFERENCES}

AKANJI, M.A., YAKUBU, M.T. 2000. $\alpha$-Tocopherol protects against metabisulphiteinduced tissue damage in rats. Nigerian Journal of Biochemistry and Molecular Biology,15(2), 179-183.

BABA, N., KIM, S., FARRELL, E.C. 1976. Histochemistry of creatine phosphokinase. J. Mol. Cell. Cardiol. 8, 599-617. http://dx.doi.org/10.1016/00222828(76)90046-8.

Badorff C., Birgit F., Robert E. R., Andreas M. Z., Alexander M., Stefanie D. and Kirk U. K. (2000). Nitric Oxide Inhibits Dystrophin Proteolysis by Coxsackieviral Protease 2A through S-Nitrosylation: A Protective Mechanism Against Enteroviral Cardiomyopathy. Circulation. 102, 2276-2281. PMID:11056105

BAILEY, L. 1976. "Hortus Third, A Concise Dictionary of Plants Cultivated in the United States and Canada", Macmillan Publishing Co., INC (New York), and Collier Macmillan Publishers (London), p. 201.ISBN 10-0025054708.

BARBOSA, P.A., DA SILVA, P.B., PARENTE, J.P. 2012. Evaluation of the gastroprotective activity of Calliandra haematocephala extracts; Planta Med. 78, P I448.http://www.thieme-connect.de/DOI/DOI?10.1055/s-0032-1321135

BARTELS, H., BOHMER M. 1971. Eine mikromethode zur kreatininbestimmung. J. Clin Chem Acta. 32, 81-85.

BELFIED, A., GOLDBERG D.M. 1971. Hydrolysis of adenosinemonophosphate by acid phosphatase as measured by a continuos spectrophotometric assay. J. of biochemical medicin. 4(2), 135148.http://www.ncbi.nlm.nih.gov/pubmed/5167444

BENSON, L. 1957. "Plant Classification", Oxford and IBH Publishing Co., New Delhi, Calcutta and Bombay, pp. 244-5.

BERGELSON, J.M., CUNNINGHAM, J.A., DROGUETT, G., KURT-JONES E.A., KRITHIVAS, A., HONG, J.S., HORWITZ, M.S., CROWELL, R.L. FINBERG R.W. 1997. Isolation of a common receptor for coxsackie B viruses and adenoviruses 2 and 5. Science. 275, 1320-1323.PMID: 9036860.

BERGMYER, H.V., HERDER, M., REJ, R. 1986a: Approved recommendation (1985) on IFCC methods for the measurement of catalytic concentration of enzymes Part 2 IFCC method for aspartate aminotrnsferase. J. Clin. Chem. Clin. Biochem. 24, 497-510. PMID: 3734712.

BERGMYER, H.V.,BERGMYER, H.V., HERDER, M., REJ, R. 1986b Approved recommendation (1985) on IFCC methods for the measurement of catalytic concentration of enzymes Part 3 IFCC method for alanine aminotrnsferase. J. Clin. Chem. Clin. Biochem. 24(7), 481-495. PMID: 3734711 BISHOP, J.M., KOCH, G. 1969. Plaque assay for poliovirus and poliovirus specific RNAs. In: Habel, K., Salzman, N.P. (Eds.), Fundamental Techniques in Virology. Academic Press, New York, 131-145.

BLAUWET, L.A., COOPER, L.T. 2010. Myocarditis. Progress in Cardiovascular Diseases, 52 ,

274

288.http://linkinghub.elsevier.com/retrieve/pii/S0033062009000966

BOPEGAMAGE, S., BORSANYIOVA, M., VARGOVA, A., PETROVICOVA A., BENKOVICOVA, M., GOMOLCAK, P. 2003. Coxsackievirus infection of mice. I. Viral kinetics and histopathological changes in mice experimentally infected with coxsackieviruses B3 and B4 by oral route. Acta Virol., 47, 245251. PMID:15068380.

BOWLES, N.E., NI, J., KEARNEY, D.L., PAUSCHINGER, M., SCHLTHEISS H,P., McCARTHY, R., HARE, J., BRICKER, J.T., BOWLES, K.R., TOWBIN, J.A. 2003. Detection of viruses in myocardial tissues by polymerase chain reaction. Evidence of adenovirus as a common cause of myocarditis in children and adults. Journal of the American College of Cardiology, 42(3), 466472.http://dx.doi.org/10.1016/S0735-1097(03)00648-X.

CANNON, D.C., HENRY, R.J., WINKELMAN, J.W. 1974. Proteins. In clinical chemistry, principles and technics 2 nd ed. Harper and Row Hagerstown M D. P: 411.

De PALMA, A.M., VLIEGEN, I., De CLERCQ E., NEYTS, J. 2008. Selective inhibitors of picornavirus replication. Med Res Rev. 28, 823-884.PMID 18381747.

De PAlMA, A.M., HEGGERMONT, W., LEYSSEN, P., PURSTINGER, G., WIMMER, E., de CLERCQ, E., RAO, A., MONFORTE, A.M., CHIMIRRI, A. NEYTS, J. 2007. Anti-enterovirus activity and structure-activity relationship of a series of 2,6-dihalophenyl-substituted 1H,3H-thiazolo[3,4-a]benzimidazoles Biochem. Biophys. Res. Commun. 353, 628-632.PMID: 17194441.

FOHLMAN, J., PAUKSEN, K., MOREIN, B., BJARE, U., ILBACK, N.G., FRIMAN, G. 1993. High yield production of an inactivated coxsackie B3 adjuvant vaccine with protective effect against experimental myocarditis. Scand $J$ Infect Dis Suppl, 88, 103-108. PMID: 8390713.

FRIEDMAN, R.B., YOUNG, D.S. 1997. Effects of Disease on Clinical Laboratory Tests, 3rd Edition, Washington. D.C; Association for Clinical chemistry press.

GALBRAITH, D.N., NAIRN, C., CLEMENTS, G.B.1997. Evidence for enteroviral persistence in humans. J Gen Virol, 78, 307-312. PMID: 9018051

GUPTA, R., SHARMA, P., GARG, A., SONI, A., SAHU, A., RAJ, S. SHUKLA, A. 2013. Formulation and Evaluation of Herbal Effervescent Granules Incorporated with Calliandra Haematocephala Leaves Extract. Indo American Journal of Pharmaceutical Research, 3 (6), 4366- 4371. ISSN: 2231-6876.

KARBER, G. 1931. 50\% end point calculation. Archiv für Experimentelle Pathologie und Pharmakologie, 162, 480-483. 
KASHIWADA, Y., HASHIMOTO, F., COSENTINO, L.M., CHEN CH, GARRETT, P.E., LEE, K.H. 1996. Betulinic acid dihydrobetulinicacid derivatives as potent anti - HIV agent. Journal of Medicinal Chemistry, 39, 1016-1017.http://pubs.acs.org/doi/abs/10.1021/jm950922q

KINDERMANN, I., KINDERMANN, M., KANDOLF, R., KLINGEL, K., BULTMANN, B., MULLER, T., LINDINGER, A., BOHM, M.2008. Predictors of outcome in patients with suspected myocarditis. Circulation,118, 639-648. http://circ.ahajournals.org/cgi/doi/10.1161/CIRCULATIONAHA.108.769489. KUHL, U., PAUSCHINGER, M., NOUTSIAS, M., SEEBERG, B., BOCK, T., LASSNER, D., POLLER, W., KANDOLF, R., SCHULTHEISS, H.P. 2005a. High prevalence of viral genomes and multiple viral infections in the myocardium of adults with "idiopathic" left ventricular dysfunction. Circulation, 111,

893.http://circ.ahajournals.org/cgi/doi/10.1161/01.CIR.0000155616.07901.35 .

KUHL, U., PAUSCHINGER, M., SEEBERG, B., LASSNER, D., NOUTSIAS, M., POLLER, W., SCHULTEISS, H.P. 2005b. Viral persistence in the myocardium is associated with progressive cardiac dysfunction. Circulation, 112 , 1965

1970.http://circ.ahajournals.org/cgi/doi/10.1161/CIRCULATIONAHA.105.5481 56.

KYTO, V., VUORINEN, T., SAUKKO, P., LAUTENSCHLAGER, I., LIGNITZ, E., SARASTE, A., VOIPIO-PULKKI, L.M.2005. Cytomegalovirus infection of the heart is common in patients with fatal myocarditis. Clinical Infectious Diseases, 40,

688.http://cid.oxfordjournals.org/lookup/doi/10.1086/427804

683

MAHRHOLDT, H., WAGNER, A., DELUIGI, C.C., KISPERT, E., HAGER, S., MEINHARDT, G., VOGELSBERG, H., FRITZ, P., DIPPON, J., BOCK, C.T., KLINGEL, K., KANDOLF, R., SECHTEM, U. 2006. Presentation, patterns of myocardial damage, and clinical course of viral myocarditis. Circulation, 114 1581 -

1590.http://circ.ahajournals.org/cgi/doi/10.1161/CIRCULATIONAHA.105.6065 09.

MAHY, B.W.J. 2008. Coxsackie B Viruses: An introduction. Curr Top Microbiol Immunol., p323, VII XIII.PMID: 18357762.

MATSUMORI, A. 2005. Hepatitis C virus infection and cardiomyopathies Circulation Research,

144

147.http://circres.ahajournals.org/cgi/doi/10.1161/01.RES.0000156077.54903.67. MATSUMORI, A., SHIMADA, T., CHAPMAN, N.M., TRACY, S.M MASON, J.W. 2006. Myocarditis and heart failure associated with hepatitis C virus infection. Journal of Cardiac Failure, 12, 293 298.http://linkinghub.elsevier.com/retrieve/pii/S1071916405013394 .

MELNICK, J.L. 1996. Enteroviruses: polioviruses, coxackieviruses, echoviruses, and newer enteroviruses .In 'Fields Virology" (Field, B.N., Knipe, D.M., Howley, P.M., Channock, R.M., Melnick, J.L., Monath, T.P., Roizman, B., and Straus, S.E., editor). 3rd ed. Philadelphia, Pa: Lippincott Raven Publishers. pp. 655 712.ISBN:0781702534 9780781702539

MOHARRAN, F.A., Marzouk, M.S., Ibrahim, M.T., Mabry, T.J. 2006 Antioxidant Galloylated Flavonol Glycosides from Calliandra haematocephala. Natural Product Research, 20(10), $927-934$ http://www.tandfonline.com/doi/abs/10.1080/14786410500378494.

MUIR, P., NICHOLSON, F., ILLAVIA, S.J., McNEIL, T.S., AIETUNMOBI, J.F., DUNN, H., STARKEY, W.G., REETOO, K.N., CARY, N.R., PARAMESHWAR, J., BANATVALA, J.E. 1996. Serological and molecular evidence of enterovirus infection in patients with end-stage dilated cardiomyopathy. Heart, $\quad 76, \quad 243-249$. http://heart.bmj.com/cgi/doi/10.1136/hrt.76.3.243.

NIA, R., ADESANYA, S.A., OKEKE, I.N., ILLOH, H.C., ADSINA, S.K.1999. Antibacterial constituents of Calliandra haematocephala. Nig. J Nat Prod. and Med., 3, 58-60.http://dx.doi.org/10.4314/njnpm.v3i1.11761.

Onyema, H.P., Ebong, P.E., Eteng, M.U., Igile, G.O., Ibekwe, H.A., Ofemile P.Y. 2012. Histopathological Responses of the Heart, Liver and Kidney to Calliandra Portoricensis Extracts in Wistar Rats Challenged with Venom of Echis Ocellatus. J. of Applied Pharmaceutical Science. 2 (06), 164-171. DOI: 10.7324/JAPS.2012.2630, ISSN: 2231-3354

PEVEAR, D.C., FANCHER, M.J., FELOCK, P.J., ROSSMANN, M.G., MILLER, M.S., DIANA, G., TREASURYWALA, A.M., McKINLAY, M.A., DUTKO, F.J. 1989. Conformational change in the floor of the human rhinovirus canyon blocks adsorption to HeLa cell receptors. J. Virol. 63, 2002-2007. PMID: 2539499.

POTIER, P. 1991. Search and Discoveries of New Anti-Tumor compounds In Rhone-Pouleng Lecture, 150th anniversary of The Royal Society of Chemistry, Imperial College London, 10.

RAJTAR, B., MAJEK, M., POLANSKI, L., POL-DACEWICZ, M. 2008 Enteroviruses in water environment- a potential threat to public health. Ann Agric Environ Med., 15, 199-203. PMID: 19061255.

RAMSINGH, A.I., CHAPMAN, N., TRACY, S. 1997. Coxsackieviruses and diabetes. Bioessays, 19:793-800. PMID:9297970.

REJ, R., 1989. Aminotransferases in disease. Clin. Lab. Med., 9, 667-687.PMID: 2686908 .
SHEN, Y., KANL, Q.C., XU, W., CHU, Y.W., XIONG, S.D. 2009 Coxsackievirus B3 Infection Induced Viral Myocarditis by Regulating the Expression Pattern of Chemokines in Cardiac Myocytes . Iran J Allergy Asthma Immunol, 8, 1-9.

SZASZ, G.A. 1969. Kinetic photometric method for serum $\gamma$-glutamyl transpeptidase. Clin. Chem. 15, 124-136.

TABACCO, A., MEIATTINI, F., MODA, E., TARLI, P. 1979. Simplified enzymic colorimetric serum urea determination. Clin. Chem. 25, 336-337.

TOMKO, R.P., XU, R., PHILIPSON, L. 1997. HCAR, MCAR :The human and mouse cellular receptors for subgroup $\mathrm{C}$ adenoviruses and group $\mathrm{B}$ coxsackieviruses. Proc. Natl. Acad. Sci. USA. 94, 3352-3356. PMID: 9096397.

TRINDER, P. 1959. Determination of blood glucose using 4 aminophenazone . $J$. Clin. Path. 22, 246.

WAHYUNI, T.S., LYDIA, T., ADITA, A.P., EVHY, A., MYRNA, A., ABDUL, R., ATY, W., MARIA, I.L., ACHMAD, F., SOETJIPTO, NASRONUDIN, HIROYUKI, F., NOBUO, K., IKUO, S., LIN, D., CHIE, A., HAK, H. 2013 Antiviral activities of Indonesian medicinal plantsin the East Java region against hepatitis C virus. Virology J. 10, 259.http://www.virologyj.com/content/10/1/259. WANG, H., DING, Y., ZHOU, J., SUN, X., WANG, S. 2009a. The in vitro and in vivo antiviral effects of salidroside from Rhodiola rosea L. against coxsackievirus B3. Phytomedicine. 16(2-3):146-55.PMID:18818064

WANG, X., YAFENG, W., ZHE, R., CHUIWEN, Q., YICHENG, L., QINGDUAN, W., YAN, Z., LIYUN, Z., JINHUA, J., CHONGREN, Y., DONG, W., YINGJUN, Z., JIANGLIN, F., YIFEI, W. 2012. Protective Effects of 20(S)-Protopanaxtriol on Viral Myocarditis Infected by Coxsackievirus B3. Pathobiology. 79, 285-289. PMID: 22688124 ISSN: 1015-2008

WANG, Y.F., WANG, X.Y., REN, Z., QIAN, C.W., LI, Y.C., KAIO, K., WANG, Q.D., ZHANG, Y., ZHENG, L.Y., JIANG, J.H., YANG, C.R., LIU, Q ZHANG, Y.J., WANG, Y.F. 2009b. Phyllaemblicin B inhibits Coxsackie virus B3 induced apoptosis and myocarditis. Antiviral Res. 84(2), 150-8.PMID: 19699238

WEBSTER D. (1974). A study of the interaction of bromocresol green with isolated serum globulin fractions. Clin. Chim. Acta. 53 (1), 109115.

WILLIAMSON, J.F. 1981. "Sunset Western Garden Book", Lan Publisher Co. Menlo Park Calf, p256.

YIN, D., LI, J., LEI, X., LIU, Y., YANG, Z., CHEN, K. 2014. Antiviral Activity of Total Flavonoid Extracts from Selaginella moellendorffii Hieron against Coxsackie Virus B3 in vitro and in vivo. Evid Based Complement Alternat Med. 2014, 950817.PMID: 24963331

ZHANG, Y., HAIYAN, Z., CHENGGANG, H., XIAOLAN, C., YINGJIE, G., YANG, H., WENFENG, G., YE Z., SHANSHAN, G. 2006. Astragaloside IV Exerts Antiviral Effects Against Coxsackievirus B3 by Upregulating Interferong. J. Cardiovasc Pharmacol. 47, 190-195.PMID: 16495755.

ZHANG, Y., ZHU, H.Y., YE, G., HUANG C.G., YANG, Y.Z., CHEN, R.Z., CUI, X.L. 2006. Antiviral effects of sophoridine against coxackievirus B3 and its pharmacokinetics in rats. Life Sci.,78, 1998-2005. http://dx.doi.org/10.1016/j.lfs.2005.09.034.

ZHU, H. YUANYUAN, Z., GUAN, Y., ZHIXIONG, L., PEI, Z. CHENGGANG, H. 2009. In vivo and in vitro Antiviral Activities of Calycosin-7 O-b -Dglucopyranoside against Coxsackie virus B3. Biol. Pharm. Bull. 32(1), 68-73. http://dx.doi.org/10.1248/bpb.32.68 